\title{
Malraux's La Voie royale as a Royal Road of Regression
}

\author{
Anne Miriam Greenfeld \\ Louisville, Kentucky
}

I. Introduction

I n André Malraux's 1930 novel La Voie royale, a young Frenchman, Claude Vannec, and his older friend Perken, a German-Danish adventurer, travel through a region of Indochinese jungle. Vannec's interest is aesthetic, archeological and financial; along the ancient "royal way" he hopes to find Khmer statues which he plans to sell. Perken, on the other hand, is searching for another adventurer, Grabot; he also intends to consolidate his chiefdom over some of the "insoumises" tribes. He has joined with Claude, hoping to make some money from the sale of the statues to help him prevent the construction of a railroad.

The first section of the novel is largely based on Malraux's own experience in Indochina, as the author himself made clear (see Langlois, "Notice" 1145). 'But La Voie royale is far from a simple adventure story or memoir; as Walter Langlois observes in his notes to the Pléiade edition, it is "un nouveau roman où l'aventure « exotique » conduira à la métaphysique," a novel involving courage and will not only in the face of material obstacles, but of psychological obstacles as well $(1132 ; 1134)$. While I have chosen to focus on the text of La Voie royale itself rather than on what the novel may reveal about Malraux's own life, my study is nonetheless based on the assumption that fictional characters can be regarded as valid reflections of human consciousness. Indeed, as Malraux explained in an interview with André Rousseaux: "La Voie royale s'efforce de traduire (. . . ) la psychologie la plus profonde de l'aventurier, en exprimant son drame propre: le combat, conscient ou inconscient, contre l'obsession de la mort" (Langlois, "Notice" 1136). Malraux adds that the adventurer's internal battle with his obsession involves a movement toward the very death he fears (Langlois, "Notice" 1136). ${ }^{2}$ This movement toward death is motivated by the need for a sense of control, for, as Denis Boak observes, the "psychological analysis" of these adventurers "is carried out almost entirely in terms of will seeking to impose itself on everything else, even the physical body of the protagonist" (33). This study will show how the death these characters both fear and seek can be understood as the loss of their manhood and identity. The journey of each in to the jungle can be read allegorically as a regression, a plunging downwards and backwards into the unconscious in an attempt to master the origin of this threat: an internalized all-powerful Mother. To my knowledge, no critic of Malraux has read the journeys of the principal characters of La Voie royale as regressions, nor has the author himself mentioned such an interpretation. The novel itself, however, provides a wealth of evidence to support such a reading. ${ }^{4}$

I base my discussion of regression in La Voie royale on Jacques Lacan's model for early childhood psycho-social development (of males). For the benefit of those unfamiliar 
with his work I will begin with a brief summary of the basic principles of this model.

Before and immediately following birth the infant can be described as a "zero, or blank, insofar as [it] lacks both individuality and subjectivity" (Ragland-Sullivan 18). Then the neonate enters a solipsistic state, experiencing itself and the world as one; as Ellie Ragland-Sullivan explains, "the infant immediately begins to merge with images that are equated with the body" (141). During this period the infant's awareness of itself is characterized by a sense of fragmentation, "une image morcelée du corps"; it doesn't yet have a sense of itself as a unified whole, "une forme [. . .] orthopedique de sa totalite" (Lacan, Ecrits 97). This phenomenon occurs because of what Lacan calls "pre-maturation"; that is, the newborn's physical helplessness and lack of coordination despite its capacity for sensory perception (Ragland-Sullivan 18).

Between the ages of 6 to 18 months, a period Lacan calls the stade du miroir, the baby gains a sense of unity through gazing at its own image in a mirror, or at that of its first other, the mother (Ecrits 93-94). As Ragland-Sullivan explains, "narcissism is the necessary assumption of an alien ego, taken on in the erotic captivation of the infant by the image of the other" (34). She adds that "During the mirror stage the infant wants to possess the mother because she provides an object of constancy and continuity that do not reside within" (34). At this stage the baby doesn't see the mother as another identity separate from itself, but just as the mirror of the self: "The identification with a Gestalt of his own body is paralleled in the infant's relationship to the mother's imago as if it were his own" (24). The Mirror stage marks the child's entry into the Imaginary Order of cognition (Ragland-Sullivan 141).

The Mirror stage ends with the onset of the Oedipal conflict (Ragland-Sullivan 29). This crisis occurs when a third party, usually the father, enters the picture, breaking up the dyad in which the baby (boy) has the illusion that he is the center of the universe; Lacan refers to this intervening presence as the "nom du père" (278). As Ragland-Sullivan explains, for Lacan,

The early mother is internalized as the source of one's own narcissism, prior to the acquisition of individual boundaries, while the father's subsequent, symbolic role is that of teaching these boundaries - he is a limit-setter. [. . .] Structurally speaking, woman becomes identified with sameness, and man with difference. (42)

The Name- or the Law-of-the-Father introduces the experience of loss and lack: the loss of an illusory fusion with the mother and the lack in the child and its mother of what the Father has, which Lacan refers to as the Phallus (Selection 288-89). It should be noted that the Lacanian Phallus is not the physical organ itself, but a complex symbol of law, mediation and authority, as well as autonomy, individuation and personal identity (Selection 67, 285; Ragland-Sullivan 270-271). ${ }^{4}$ 
The nom du père brings laws and limits, but it also allows entry into the Symbolic Order of cognition, and the child can begin to communicate with language and become a social being. Ragland-Sullivan explains that "[i]nstead of treating images as if they were real, the post mirror child begins to represent them in words and so passes from a state of 'nature' to one of culture and language" (29). She adds that "Symbolic (i.e., differential) elements - the ability to name things - replace Imaginary ones (i.e., images) in an identificatory reshaping of the subject" (29). Entry into the Symbolic Order also brings with it an opening up of the unconscious and an accompanying awareness of what Malcolm Bowie calls "otherness within"; as Lacan stated, "L'inconscient, c'est le discours de l'Autre" (Bowie 118, quoting Lacan). The child is now able to perceive not only the world, but also itself, as Other.

I suggest that in La Voie royale there exists an inverse relationship between each character's age and the stage of psycho-social development at which he begins his journey. In this novel, "older" appears to correspond to "more primitive," that is, to a deeper and more ancient stratum of the unconscious. Grabot, father figure to Perken, is the most infantile: when first described, he appears to be entirely self-absorbed and solipsistic. Grabot's journey into the jungle results in aphasia, blindness and castration, a condition resembling a fetal state. Perken, on the other hand, begins his journey well aware of the existence of others: for him, the ultimate Other is Woman. He is fundamentally narcissistic, however, and sees women only as mirrors affirming his own existence. Perken's regression will take him back through a fragmented and solipsistic infantile state, and will end in death. Claude Vannec, the youngest of the three, is more developed psychologically and socially than the others, although he too is not a fully realized adult. When the novel opens Claude is at the threshold of the Oedipal crisis, but finds himself unable to move forward through its resolution. Not only is he isolated and alienated from the society of other men, but he also appears confused about his own gender identification. Of the three principal characters, only Claude succeeds in working through the past in order to move forward successfully into adulthood, and Grabot and Perken serve him as instructive mirrors in his own growth process.

\section{Grabot: Another Ubu enchaîné}

We know very little about Grabot's past; he first appears as an almost mythic figure, without antecedents, sui generis. He is presented as a big self-centered baby; in his photograph he appears to Claude both brutal and childish (446). Grabot is strikingly Ubulike, so solipsistic and isolated as to seem not quite human.

Il n'a jamais réfléchi qu'à lui-même, qu'à ce qui l'isole plutôt, mais comme d'autres pensent au jeu ou au pouvoir ... Ce n'est pas quelqu'un, mais c'est quelque chose. [. . . ] C'est un homme réellement seul [. . .] (439-440)

According to Perken, Grabot fills his solitude with "courage" (440), but in Claude's 
view, this courage serves him primarily as an opportunity for self-admiration (440). Perken seems to agree, remarking that "Il y a dans tout cela un immense orgueil primitif" (441). However, Grabot's "courage" actually consists of largely self-destructive and masochistic behavior. Motivated by a need to control everything, Grabot takes on all roles: rather than be beaten, he'lleither beat himself or he'lldictate the terms under which others beat him. For example, because he was afraid of scorpions, he had himself stung (441); at another time he deliberately infected an eye, subsequently losing it, in order to prove a point to a prison doctor (415). This masochistic "courage" also motivated his return to the jungle. Although Grabot's stated goal was to become a powerful chief, his primary motive was the desire to abuse power over women in order to establish control over his erotic obsession with being dominated by them (439). ${ }^{5}$ Perken explains this to Claude:

- Je vous ai parlé d'un homme qui se faisait attacher, nu, par des femmes à Bangkok ... C'était lui. Ce n'est pas tellement plus absurde que de prétendre coucher et vivre - et vivre - avec une autre créature humaine ... Mais lui en est atrocement humilié ...

- De ce qu'on le sache?

- On ne le sait pas. De le faire. Alors, il compense. C'est sans doute pour cela surtout qu'il est venu ici. . . Le courage compense ... (447)

I suggest that underlying Grabot's relations with women is an unresolved feeling of subjugation to an internalized Mother, and that his return to the jungle is motivated by the desire to destroy Her power over him. The result, however, will be the same as it has been in other areas where he shows "courage": he himself is the only one to suffer. Just as Grabot had been tied up by women, he is once again bound by those he had wished to dominate, "attaché par des courroies de cuir" (456). Instead of ending in his own imagined triumph over the tribal women, Grabot's return to the jungle results in helplessness, blindness and lack of identity: the condition of the unborn fetus. Grabot has been reduced to the very state from which he had sought to escape.

When Claude and Perken find Grabot, he is incarcerated in a dark, womb-like hut (455); the use of the word "enceinte" to describe the surrounding area adds to the impression that the hut is a kind of uterine enclosure (465). Their initial perception of Grabot even calls into question his identity as a human being: at first they see only moving shadowy objects, then "quelquechose" pulling a horizontal crossbar (455). Their focus remains on this beam, and only when the entire "machine" is identified do they look towards the agent of the movement.

Elle pivotait autour d'un grand baquet, d'une cuve ... Elle tournait vers eux, perdant sa forme à mesure qu'elle s'éloignait de la projection éblouissante de l'ouverture plaquée sur la poussière du sol autour de leurs silhouettes

\section{LittéRéalité 26}


enchevêtrées, aux longs troncs et aux courtes jambes. Et toute la machine apparut enfin dans le rectangle de soleil qui tombait de la porte: une meule. [....] Attaché à la meule, il y a avait un esclave. De la barbe sur le visage. Un Blanc? (455)

When Perken calls his name, Grabot extends his open hand as if to grasp something, and lets it fall with "un bruit de chair" (456). Grabot's language is like that of newborn babies, a language of the body, a "langage de chair": "Ce corps savait parler -- dès que s'était ouvert la case de la meule, cette main tendu pour manger, ce dos habitué au caveçon - et seulement de ce qu'il avait souffert" (461). Grabot has lost his voice, his language, his human identity. When he does finally speak, it is with "une voix au timbre faux," and he uses the language of his captors rather than his own (456). Although he eventually speaks in French, his voice remains strange and broken, and he himself seems unable to distinguish the human from the non-human, asking "What are you?" rather than "Who are you?" (456). Perken's and Claude's reaction to "cet être" is "l'horreur de l'inhumain" (456). Claude despairs of finding coherent thought behind this "visage effacé" (456) and when Perken asks for the second time what has happened, Grabot can only croak "Rien" (457).

Grabot is both alive and not alive: Claude refers to him as "un mort" and "ce cadavre" (457). His regression has taken him back to the death-in-life limbo of the womb, and when Perken cuts the cord attaching Grabot to the millstone it is like cutting the umbilical. Despite his apparent liberation, however, Grabot continues to walk in a circle, "retourné à son esclavage" (466). Just as he had provided himself with the illusion of being in control of all his other pain by inflicting it himself, so he continues this illusion by becoming the "master" of his own slavery, taking on the role of his persecutors. Grabot's journey of regression results in his entrapment in a masochistic circle of his own making; his royal road leads him to a dead-end, forever subjected to an internalized Mother's power.

\section{Perken, or the Death of Narcissus}

One of Perken's motives for his trip into the jungle is to find Grabot, who serves him as both a role model and lost father figure. As Rhonda Garelick points out, "He [Perken] clearly sees Grabot as his immediate predecessor, as someone on whom to model his own career"; she adds that "[h]is admiration for Grabot is not unlike Claude's for his Viking grandfather" (185). Perken's return to the jungle is also motivated by his fear of death and of the loss of his own manhood: he hopes to consolidate a chiefdom and thereby renew his erotic life with the tribal women he would dominate. Aging and impotence represent for Perken the loss of power over women/the Other; he wants to return to a situation in which his potency, his power of domination, will be assured. This agenda involves him in a regression from the Lacanian Mirror stage to a solipsistic state, and will culminate in the same pre-birth condition in which Grabot remains trapped. But in Perken's case, the result will be death. 
Perken has always been profoundly narcissistic in his relations to women, seeing them primarily as objects, not other human beings with their own separate subjectivity. From the start he stresses to Claude the importance of women's status as simply "the other sex":

- L'essentiel est de ne pas connaître la partenaire. Qu'elle soit: l'autre sexe.

- Qu'elle ne soit pas un être qui possède une vie particulière? (373)

Perken sees women as mere bodies, as things to be owned, and as enemies if they remain "un-owned": "Tout corps qu'on n'a pas eu est ennemi" (413-414). Indeed, Perken's description of the natives' sexual practices shows his fascination with the possibility of possessing a woman so completely that he could feel her sexual feelings, usurp her orgasm and engulf her subjectivity into his own: "[J]e commence à comprendre leurs cultes érotiques, cette assimilation de l'homme qui arrive à se confondre, jusqu'aux sensations, avec la femmme qu'il prend, à s'imaginer elle sans cesser d'être lui-même" (414).

Perken will ultimately fail in this endeavor, however. When he has sexual relations with a prostitute near the end of his life he realizes he'll never be able to own her desire and jouissance: "ce corps affolé de soi-même s'éloignait de lui sans espoir; jamais, jamais il ne connaîtrait les sensations de cette femme, jamais il ne trouverait dans cette frénésie qui le secouait autre chose que la pire des séparations" (487). Perken believes that he fails to take over her sensations because he doesn't love her, but he understands love only as possession of the Other, the integration of the Other into the self: "On ne possède que ce qu'on aime" (487). According to Claude, Perken's desire to possess women to the extent of experiencing their orgasms is born of a longing for self-annihilation: "Ce qu'il veut, pensait Claude, c'est s'aneantir" (414). This erotic suicidal urge is the underlying motivation for Perken's journey into the jungle: a death-wish longing for a return to the womb where the fetus and the mother are joined.

It is after Claude and Perken have found Grabot that Perken manifests most explicitly his return to infancy, to what Lacan calls the "pre-maturation" period, before the onset of language, when the child can neither speak nor control its own body movements. As Perken walks toward the tribal chief he loses his mental acuity: "Toute pensée précise était anéantie" (466). Furthermore his steps become stiff and jerky, and he can't bend his knees: "Chaque pas des jambes raidies retentissait dans ses reins et son cou [. . . la la résistance de son corps [...] retombait d'une jambe sur l'autre avec une vibration que coupait le pas suivant" (467).

As a result of his regression Perken forfeits his power as an adult man, a loss symbolized by his giving up his gun: he holds his revolver as if it is a ransom and then drops it when told to (467). It is significant that only at this moment does he realize that Grabot has been castrated as well as blinded - "un double cadavre" - and that such a fate awaits him as well: "il pensa soudain que sans doute ils n'aveuglaient pas seulement leurs esclaves, mais

\section{LittéRéalité 28}


les châtraient" (467).

Perken's subsequent behavior reveals his psychological kinship with Grabot, for he shows himself to be infected with the same "lèpre du courage" which had destroyed his role model (466). Although Perken sees the revolver lying on the ground, like a living being ("Vivante" [468]) which could help him ("capable de toutes les défenses" [468]), instead picking it up, he kicks it away. Perken deliberately relinquishes the gun and moves toward the very thing he most fears - castration and death - in order to give himself the illusion of control over his own destiny. This choice sends him back to a time before his manhood, before his entry into the Symbolic, before his acquisition of the power of the phallus: the death-in-life of pre-birth. The very description of Perken's dying process suggests a willful return to the womb: "cette fuite vers un monde aussi elémentaire que celui de la forêt" (503). His plunge toward death recalls his longing for a self-annihilating joining with women: "Jeté sexuellement sur cette liberté à l'agonie, soulevé par une volonté forcenée se possédant ellemême devant cette imminente destruction, il s'enfonçait dans la mort même" (469).

Perken's threatened castration and his regression toward a fetal state are foreshadowed by his view of the Mois and their fetishes. Looking out of the hut where he and the others were hiding, he had seen a pair of fetishes, male and female, like parents, "tenant à pleines mains leur sexe peint en rouge" (464). The verb used to describe the way their fingers clutched their sex organs is "s'encastrer" (464), a word which calls to mind not only castration but self-castration. Beyond the fetishes there was a hut, and the Moîs disappeared behind it as if into a trap-door (464). This disappearance resembles a return to the womb: the Moïs who file behind the hut are called "sous-hommes," transformed suddenly into "néant menaçant" (464).

It is toward just such a state of nothingness that Perken is bound as he is dying of gangrene. One phase of this process involves his reversion to the pre-mirror stage sense of fragmentation: "Tout ce qu'il avait pensé de la vie se décomposait sous la fièvre comme un corps dans la terre" (501). Perken's regression to a completely solipsistic state begins as he identifies with the whole world. He sees the train tracks on his body, "sur son vrai cadavre, sur ses yeux pourris, sur ses oreilles," and he hears the sound of trees falling in his pulse, "dans les battements de son sang" (502). He feels tied to the train "comme par une corde de prisonnier" (502); I suggest that this cord is like the umbilical cord, tying him to a kind of World-Mother with whom he identifies. Perken is alive, but he is imprisoned underground in her body: "Prisonnier, encore enfermé dans le monde des hommes comme dans un souterrain" (503).

Perken feels disconnected from his hand and fingers, indicating his increasing sense of fragmentation: "Un son de chair le surprit: c'étaient ses doigts fascinés par la brûlure des insectes qui tambourinaient convulsivement sur la charette sans qu'il s'en fût aperçu" (501). Finding Claude "haïssable" because he is still so involved with life (503), Perken begins to focus instead on his own hand as his only companion, "cette chose fidèle posée sur sa cuisse" (503). He considers his hand a kind of disembodied witness, "libre, séparée de lui," watching 
what appears to be his return to the womb: "Là, calme sur sa cuisse, elle le regardait, elle l'accompagnait dans cette région de solitude où il plongeait avec une sensation d'eau chaude sur toute la peau" (503). Perken's hand represents an externalized projection of his own consciousness in this formless primitive world: "une conscience atroce demeurait: cette main était là [...] devant lui dans le monde informe où il se débattait, ainsi que les autres dans les profondeurs gluantes" (503). His hand, his consciousness, is all that remains alive as his eyewitness: "simple, naturelle, mais vivante, comme un oeil" (503).

Soon Perken loses all contact with the outside world, aware only of feeling lost in an "immensité blanche à force de lumière" which is filled gradually with his own heartbeat (503). He even loses his hand-consciousness and is aware only of pain: "Il n'avait plus de main, plus de corps sauf la douleur" (504). Perken's pain is associated with the pains of childbirth; he identifies with the Mother in whose womb he is dying: "La souffrance l'exaltait encore; mais elle devînt plus intense, et elle le transformerait en fou, en femme en travail qui hurle pour que s'écoule le temps" (505).

Although Perken's hand-consciousness returns for a moment -- "Sa main reprit vie" -- he continues to identify with the World (Mother), confusing the sound of his blood with that of the river: "Elle [sa main] était immobile, mais il y sentait l'écoulement du sang dont il entendait le son fluide qui se confondait avec celui de la rivière" (504). Perken's final words are an expression of this solipsistic state. He dies believing that no death exists outside the self, that all that exists is the self who dies, containing death as it contains everything else.

$$
\begin{aligned}
& \text { «Il n'y a pas ... de mort ... Il y a seulement ... moi ... } \\
& \text { Un doigt crispa sur la cuisse. } \\
& \text { «...moi ... qui vais mourir ... }(506)
\end{aligned}
$$

IV. Claude: Rebirth, Rejection and Reconciliation

\section{A. Rebirth}

In their article "Cyclic Time in Malraux's La Voie Royale" Stary and Rowland observe that Claude is portrayed throughout the novel as "drowsily dominated by his subconsciousness" (49), and they argue that it is his dream-like reverie early in the novel which sets in motion the subsequent action (50). Freud called the dream "the royal road to the unconscious" (Ragland-Sullivan 12); Claude's journey not only follows the path of his dream, but it constitutes an internal voie royale to the center of his primordial self. This road will engage Claude in a regression through the Mirror stage to the pre-mirror sense of fragmentation and ultimately to the womb itself, but unlike the journeys of Grabot and Perken, his will result in a kind of rebirth.

Although Claude, like Perken, has been brought up by his grandfather, he continues to be preoccupied by his mother, and in particular by her obsession with her own aging 
process. Claude's mother died of what he refers to as "un retour d'âge prématuré" (381); the ambiguity of these words points to a clear parallel between regression and the movement forward in time toward death. Claude's memories of his mother at this juncture in his life are inspired by his identification with her; indeed, his regressive journey into the jungle parallels her déchéance, and his own hysteria while there is caused by his lack of separation from her. ${ }^{6}$ Claude's obsession with entering the jungle to remove the statues involves a drive to be free of the grasp of this mother he has internalized.

In order to accomplish his goal of separation and autonomy Claude attempts to rectify his past experience by "re-doing" it, by regressing to a metaphorical womb in order to be reborn symbolically. Claude begins his regression with a return to the narcissism of the Mirror stage, which can be seen in his earliest relations with Perken. As soon as the older man agrees to accompany him on his journey, Claude ceases to see him as another man and perceives him instead as the mirroring gaze of the Other that allows him to get a sense of himself as a unity.

Sitôt après l'acceptation, cet homme n'existait pas. Il suivit le regard de Perken: c'était son image, à lui, Claude, que ce regard fixait, mais dans la glace. Son propre front, son menton avançant, il les vit, une seconde, avec les yeux d'un autre. (394)

Claude associates the jungle with his mother, in particular regarding the notion of decomposition: "L'odeur de décomposition des étangs enveloppait Claude, qui revit sa mère errer à travers l'hôtel de son grand-père" (411). The decomposition of the jungle leads to Claude's own sense of coming apart: he refers to the "décomposition de l'esprit dans cette lumière d'aquarium, d'une épaisseur d'eau" (416). He is descending to the darkness and obscurity of his unconscious, regressing to a pre-mirror sense of fragmentation. All is the same in the jungle; there is no differentiation, there are no distinctions. Claude has entered a realm before the Symbolic and the nom-du-père: "L'unité de la forêt, maintenant, s'imposait; depuis six jours Claude avait renoncé à séparer les êtres des formes, la vie qui bouge à la vie qui suinte" (417). And who is responsible for all this? It is "une puissante inconnue" who attaches the fungus to the trees and makes everything swarm in "ces bois fumants du commencement du monde" (417). It is indeed the beginning of Claude's world, before meaning, before will, and this powerful unknown feminine presence can be understood as both Jungle and Mother.

Once Claude arrives at a temple where sculptures might be found and detached from the larger structure, his regression to infancy becomes even more marked: he must crawl on his belly, and then must move on hands and toes. His lack of coordination resembles the prematuration phase described by Lacan: "Il avançait lentement, exaspéré par le peu d'obéissance de son corps maladroit" (419). Claude makes for a gap, an opening, an exit . $\ldots$ as if he is in a birth canal, moving toward the light outside the womb (420). When he 
finally emerges from this hole he can climb down the wall and run like a man ("libre enfin de courir comme un homme" [420]). However, there are no sculptures here for him to remove; the monument is unfinished, and Claude's own "rebirth" process also remains incomplete.

Claude and Perken finally come to a temple with statues, and Claude repeats the same process: he must walk on hands and toes and move through the darkness toward the light seen through a "troué." (424). When Claude succeeds in emerging from this opening - like another birth canal - and he can stand once again, he sees the sculptures. His ensuing struggle to break them free from the stone wall resembles a baby's struggle to be born; he identifies with the sculptures, and feels that his own life is at stake: "[I]l s'arc-bouta et poussa le bloc, de toute sa force. [.. . ] c'était sa vie menacée qui était là ... Sa vie" (428). The wall, described in human terms, resembles in turn a mother refusing to release an infant from her womb: "chargée d'hostilité" (427), "opiniâtre, être vivant, passif et capable de refus" (428). Claude's mental condition here corresponds to the pre-mirror stage. He is almost unconscious as he strikes the rock, without awareness - "Claude frappait presque sans conscience" - and his thoughts are fragmented - "Sa pensée en miettes" (429).. When the hammer breaks, Claude feels dependency, loss of will, even a loss of flesh, as if his very blood, pulse by pulse, is leaving him: he is sliding back into the womb (430). He then imagines himself in a fetal position, losing consciousness, giving up his struggle with the relief of passively accepting the power of the Jungle/Mother:

Il s'imagina là, les bras serrés contre la poitrine comme par la fièvre, recroquevillé, perdant toute conscience, obéissant avec le sentiment d'une libération aux sollicitations de la brousse et de la chaleur. (430)

Claude rallies, however, feeling once again the need to defend himself against this implacable stone wall, this enemy, this imprisoning womb. Like a baby pushing its way out of its mother's body, Claude acts instinctively, without reason, fighting for his life: "Il ne s'agissait plus de vivre avec intelligence, mais de vivre. L'instinct [. . .] le portait contre cette pierre, les dents serrées, l'épaule en avant" (430). The stone represents the Mother from whom Claude is struggling to escape: "Il se sentait lié à elle par la haine comme à un être animé; et c'était bien ainsi qu'elle gardait le passage et qu'elle le gardait lui-même, qu'elle se chargeait soudain de l'élan qui depuis des mois portait sa vie" (430).

After the sculpture falls, Claude is at peace: "En face de cette pierre tombee, la cassure en l'air, un accord soudain s'établissait entre la forêt, le temple et lui-même" (431). He has separated himself not only from the Jungle/Mother's thrall, but also from his obsession with the feminine side of himself, represented by the female statues. Referring to Claude, Bettina Knapp observes that "The loosening and dislodging of the dancing figures from the monument, which had buried and imprisoned them during the course of centuries, was paralleled in the psychological sphere by a release from the bondage of these negative 
feminine forces incarcerated within him since childhood" (Knapp 37). I claim, however, that these "feminine forces" were negative only in that they had remained repressed: Claude's goal was not to destroy the female statues, but to own them and to make use of them, to integrate them into his life. While Claude is now free from hysteria, the uterus which had mastered him, he has at the same time claimed "ownership" of the feminine within himself. Although he will leave the statues themselves in the jungle in order to follow Perken, he takes with him the "otherness within" they represent. Claude's acceptance of his feminine aspect, reflected in his relationship with both Grabot and Perken, will ultimately be reconciled with his successful resolution of the Oedipal conflict.

\section{B. Rejection}

When Claude meets Grabot he immediately identifies with him, unconsciously imitating his inability to speak and see. For example, when Claude wants to question Perken about Grabot, he finds himself incapable of pronouncing the word "aveugle" (456); later he is silenced by "un désespoir de muet" (456). When he attempts to communicate with Grabot, Claude feels imprisoned in his own "univers de formes" - the Symbolic - and then mimics Grabot's blindness: "Il ferma ses propres yeux, serrant ses paupières, cherchant d'autres mots" (461).

Not only does Claude identify with Grabot, but he sees him as a kind of distorted mirror, reflecting back to him an image of himself he doesn't want to accept. When Claude momentarily considers killing Grabot it is because he would rather destroy this mirror and reject its message than commit suicide: "[S]'il avait tire, il aurait tourné l'arme, au dernier moment, contre Grabot, pour supprimer ce visage, cette haine, cette présence -- pour chasser cette preuve de sa condition d'homme, comme l'assassin qui coupe son doigt révélateur" (463).

What is this "condition d'homme" which Grabot shows Claude, and which Claude rejects? Is it his human condition, or rather his condition as a man? And what is meant by "l'assassin qui coupe son doigt revélateur"? The assassin who might point to himself as a killer, so he must cut off that finger? Or perhaps also the man who considers his very manhood murderous, so he castrates himself? Claude perceives Grabot as both his own finger and the power of the Phallus, pointing back at him accusingly, showing him that to be a man he must also be a murderer. Grabot's purpose in coming to the jungle was to abuse women as a compensation for his erotic need to be dominated by them; underlying this goal was his desire to destroy an internalized Mother in order to be free of her power over him. It is this image of "man" as synonymous with "abuser of women" and "mother-killer" that Claude wants to destroy by shooting Grabot in a symbolic act of self-castration.

So what prevents him? No clear explanation is given, but for just a moment Claude feels the absurdity of his existence leave him, and he lets his hand drop (463). If Claude has learned one thing clearly from Grabot, it is that murder, self-mutilation and suicide will not help him; he rejects these options, and the image of manhood Grabot presents as well. It will 
be through his friendship with Perken that Claude will learn to resolve his own inner conflicts.

\section{Reconciliation}

When Claude began his journey he had been on the threshold of the Oedipal crisis, unable to resolve it and move on into the Symbolic Order of laws, language, and participation in the community of others distinct from the self. Perken's presence on the ship was essential for Claude, for despite the older man'sown regressive agenda, Claude required the presence of a father figure, if only as a representation - a nom-du-père if not a real one - in order to succeed in his process. As Rhonda Garelick observes, "Claude transfers his Oedipal admiration and resentment from the figure of his grandfather to Perken" (185).

Perken represents for Claude not only a father/grandfather figure, however, but also a reflection of his own difficulty resolving the Oedipal conflict. Claude first sees Perken in a brothel in Djibouti, physically dominated by a large woman, his own form unclear: "il avait entrevu, sous le bras tendu d'une grande négresse diaprée de rouge et de noir, la forme confuse de Perken" (376-77). It is as if Claude perceives Perken as a boy without identity overshadowed by a powerful dominating mother. This passage is immediately followed by Claude's reflection that Perken represents his own possible future isolation from the fellowship of male society: Claude feels drawn to him "comme s'il eût prophétiquement vu son propre destin: vers la lutte de celui qui n'a pas voulu vivre dans la communauté des hommes, lorsque l'âge commence à l'atteindre et qu'il est seul" (377).

Claude's acceptance of the feminine side of himself is also reflected in his perception of Perken. When Perken smiles, for example, Claude sees him as "moins masculin" (382), and as Thomas Jefferson Kline points out, "Claude enviously compares Perken's charisma to 'a woman's charm' (p. 32:42), identifying the older man with his own idealized selfimage" (33). However, although Claude admires and identifies with what he perceives as Perken's feminine aspect, it is through his loyalty to the older man that he also succeeds in entering the Symbolic Order of the fraternité virile.

As Perken is dying, Claude seeks a language with which to express his own sense of fraternity with him, "cette fraternité désespérée qui le jetait hors de lui-même" (506). Yet the novel closes with a description of Claude as both witness and outsider: "Perken regardait ce témoin, étranger comme un être d'un autre monde" (506). Claude is now able to identify with the Other in compassion, but is distinct from the Other as a separate subjectivity, of another "world." Claude's sense of fraternity has also "thrown him outside of himself," enabling him to become a witness of his own life as well. Reflecting the artistic development of his creator, Claude has left the limitations of the solipsistic "voix de gorge" and the narcissistic obsessions of the farfelu kingdom of the Imaginary. Not only has he has learned to hear the voice of the Other, but he has also learned to hear himself as an Other, "la voix des oreilles." And in his acceptance of his own feminine aspect, Claude has come to acknowledge and accept the presence of otherness within himself. 


\section{Works Cited}

Boak, Denis. André Malraux. Oxford: Clarendon Press, 1968.

Bowie, Malcolm. Freud, Proust and Lacan: Theory as Fiction. Cambridge: Cambridge UP, 1987.

Freud, Sigmund. "The Economic Problem of Masochism." The Standard Edition of the Complete Works of Sigmund Freud. Trans. and Ed. James Strachey. Vol. XIX (1923-1924). London: The Hogarth Press, 1962. 159-170.

Garelick, Rhonda K. "La Voie royale and the Double Time of Art." André Malraux. Ed. Harold Bloom. New York: Chelsea House Publishers, 1988. 181-192.

"Hysteric," The American Heritage Dictionary, 1979 edition, 650.

Jenkins, Cecil. André Malraux. New York: Twayne, 1972.

Klein, Thomas Jefferson. André Malraux and the Metamorphosis of Death. Columbia UP, 1973.

Knapp, Bettina. "Malraux's La Voie royale: Heroes in exile." Revue André Malraux Review. 20:2 (Fall 1988). 24-44.

Lacan, Jacques. Ecrits. Paris: Seuil, 1966; Ecrits, A Selection. Trans. Alan Sheridan.

(New York: W.W. Norton and Co., 1977.

Langlois, Walter. André Malraux: L'Aventure Indochinoise. Paris: Mercure de France, 196; "Notice" to La Voie royale. Oeuvres complètes. André Malraux. Paris: Pléiade, 1989. 1123-1144.

Malraux, André. La Voie royale. Oeuvres complètes. Paris: Pléiade, 1989. 371-506.

Ragland-Sullivan, Ellie. Jacques Lacan and the Philosophy of Psychoanalysis. Urbana and Chicago: U of Chicago P, 1986.

Rousseaux, André. "Un quart dheure avec M. André Malraux," Candide, 13 nov.1930.

Stary, S. G. and M. L. Rowland. "Cyclic Time in Malraux's La Voie royale." Neophilologus. 60, 1976. 49-55.

\section{Notes}

'For a detailed description of this period in Malraux's life, see Walter Langlois' André Malraux: L'Aventure Indochinoise, Paris: Mercure de France, 1967.

${ }^{2}$ Both references are cited from "Un quart d'heure avec M. André Malraux," Candide, 13 nov. 1930.

${ }^{3}$ In her Jungian interpretation of La Voie royale, Bettina Knapp refers to the jungle as a "womb-like sphere" and the domain of the "Terrible Mother, or the destructive aspect of the female principle," a "powerful and dominating force buried deep within the unconscious," representing the "would-be hero's primordial enemy" (33). Although Knapp's analysis is highly suggestive of the notion of regression, she limits herself to a discussion of myths and 
archetypes.

${ }^{4}$ See Lacan, "La Signification du Phallus," Ecrits, Paris: Seuil, 1966, 685-695 (especially 686, 690, 692 and 694), and Ragland-Sullivan, "Beyond the Phallus? The Question of Gender Identity," Jacques Lacan and the Philosophy of Psychoanalysis, Urbana and Chicago: U of Chicago P, 1986, 267-308.

${ }^{5}$ Grabot's erotic need to be dominated by women follows the masochistic pattern described by Freud in which the "victim" takes an infantile position in sexual relations.

[...] the manifest content [of the phantasies] is of being gagged, bound, painfully beaten, whipped, in some way maltreated, forced into unconditional obedience, dirtied and debased. [. . .] The obvious interpretation, and one easily arrived at, is that the masochist wants to be treated like a small and helpless child, but, particularly, like a naughty child. (162)

${ }^{6}$ Note that the word "hysteria" derives from the Greek word for "uterus." "Hysteric," The American Heritage Dictionary, 1979 edition, 650. 